EPRA International Journal of Economic and Business Review-Peer Reviewed Journal

Volume - 8, Issue -12, December 2020 |e-ISSN: 2347 - 9671| p- ISSN: 2349 - 0187

SJIF Impact Factor (2020): 8.107|| ISI Value: 1.433|| Journal DOI URL: https://doi.org/10.36713/epra2012

\title{
AN OVERVIEW OF COMMERCE EDUCATION IN INDIA
}

\begin{tabular}{|c|c|}
\hline Dr. Dhanraj Jain & $\begin{array}{c}\text { Principal, Shri Lalchand Milapchand Dadha Jain } \\
\text { College, Osian, Jodhpur (Raj) }\end{array}$ \\
\hline Dr. Jatan Kanwar Jain ${ }^{2}$ & $\begin{array}{c}\text { Ex Associate Professor, Department of Business } \\
\text { Finance \& Economics, FCMS, Jai Narain Vyas } \\
\text { University Jodhpur (Raj.) }\end{array}$ \\
\hline
\end{tabular}

\section{ABSTRACT}

Article DOI URL: https://doi.org/10.36713/epra5979

Generally Commerce includes exchange of goods and services and the things which ease them. In India commerce education is playing an important role in boosting the economy. Commerce students get the places in various sectors like banking, insurance, finance, foreign trade etc. So it is very important to focus on this issue. Some serious threats are arising for the commerce education now days like rising unemployment among commerce students, outdated syllabus etc. Important studies and literature has been reviewed to get the real picture. It has been found that students are losing interest towards the commerce education. This paper can be a good attempt to draw attention towards opportunities, challenges and future of commerce education in India.

KEY WORDS: Commerce Education, Higher Education, Education System, Education in India, Education

\section{INTRODUCTION}

In India, commerce as an educational stream is first opted at intermediate level i.e. at $10+2$ level or after Class 10th. B.Com is awarded to students if he/she pursues commerce at the undergraduate level. For example, if a candidate chooses to study Accountancy as major at Bachelors level then B.Com. (Hons.) in Accountancy is awarded. The student who makes outstanding performance in the final examination is awarded with distinction.

Commerce opens a lot of possibilities to students in India. Once can pursue a course in
Chartered Accountancy, Cost Accountancy, Company Secretaryship or even Law. For careers in Commerce. As said by Chesseman, Commerce training is a type of guidelines that straightforwardly just as by implication readies an agent for his calling. It gets ready understudies for socially alluring and by and by productive professions in the field of business and money. While seeking after advanced education in Commerce in India, understudies secure the information on business exchange, variances in the market, financial strategies, nuts and bolts of financial aspects, mechanical approaches, and so forth. The 
instruction bestowed to Commerce understudies will in general furnish them with various particular aptitudes that assist them with exceeding expectations in various utilitarian regions of exchange, industry and business.

\section{REVIEW OF LITERATURE}

Rust and Oliver (1984) in their examination gave three elements of model to estimation of administration quality generally over the administration which is broadly known as desire model.

The Karnataka Universities Review Commission (1993) it suggested that the University can not, stay uninvolved of the happenings occurring around it. A functioning interest of accessible specialists at the college level in taking care of the issues of modern improvement is, critically required.

Eresi, K. (1994) advocated each establishment bestowing business training ought to have such a MOU with industry/business houses to attempt improvement of different aptitudes in taking care of genuine business circumstance.

Swaminathan D.(1995) highlighted the Cooperation and reliance are the very much perceived ideas in the current day worldwide circumstance. Colleges are no special cases to this. They should come out from their ivory tower ideas and connect with the outside world.

Parida and Parida (1996) saw that the methodology of business instruction and b u s I n e s training is not quite the same as one another. They have obviously expressed as "the cloister, for the Indian economy is carry for Excellency in business instruction. We have IIMs and private administration establishments for granting same.

The High Powered Committee on Restructuring of Commerce and Management Courses in Karnataka (1999) advocated the essential issue with trade training as apparent by the businesses, identifies with the wide break that exists between the standards learnt in the study halls, and what is polished in business foundations.

Mahajan and Shah (2000) presumed that in the course of the last over 10 years or thereabouts, worldwide rivalry and expansion of business instructive foundations over the world have hardened difficulties to the business colleges in India to deliver quality items that could take into account the necessities of corporate world and endless supply of various partners of business training.

Khairoowala et. al. (2002) felt it basic with respect to business educationists to clear to the need of the market by giving business training in sensible way with a down to earth contact through better linkage among Universities and Industries.

Gupta et. al (2003) saw that the Indian business colleges have tried to recreate the US-based hierarchical, educational, educational programs, industry-interface, and scholastic examination models, however are attempting to present a few adjustments.

Ahmad (2004) underscored for achieving changes in the framework and the teaching process. Not with standing conferring scholastic information, prepared to take care of the issues going up against the business world from everyday. This would require the rebuilding of business prospectuses at ordinary stretches. He additionally felt that in the period of specialization business instruction ought not proceed as such an overall training making understudies handymen and ace of none.

Mishra (2005) concentrated on post-world war period trade instruction and stressed e-learning, virtual study hall and on line training. He additionally saw that we are not reacting in mindful manner while executing educational plan of business instruction. He likewise underscored on the need of changing outlook of the teaching network.

Das (2006) referenced that the term 'Trade and 'business 'training is utilized equivalently in numerous nations and frequently they are utilized reciprocally.

\section{RESEARCH METHODOLOGY}

The required data for the present study have been collected mainly from secondary sources. For the fulfillment of the above objectives, Government publications, research journals, periodicals, books \& web site through internet have been used for data collection. This study provides impetus to identity the short comings in commerce education and devise corrective strategies which if implemented leads to growth of professionalization through commerce education.

\section{Objectives of the Study}

- To analyze commerce education in India

- To make suggestions for betterment of commerce education in India

\section{SIGNIFICANCE OF COMMERCE EDUCATION}

Trade instruction helps bolster the expanding needs of business houses. It has been created to give helps to the developing labor needs in a huge number of business endeavors. Business instruction outfits understudies with particular aptitudes that come valuable in handling issues in various utilitarian zones of business, industry and exchange.

The talented labor flexibly is imperative for the development of a business. Trade instruction has a urgent job in the present unique business condition. The quickly changing patterns privatization, globalization and execution of innovation has made 
intense for associations to endure the opposition in the business world. Thus, the interest for Commerce training has expanded numerous folds. Business officials should be prepared to refresh and adjust their abilities rapidly according to the unexpected changes in the outer condition.

\section{CURRENT STATUS OF COMMERCE EDUCATION IN INDIA}

\section{Table 1}

Specialization Wise Number of Colleges (Based on Actual Response AISHE 2018-19)

\begin{tabular}{|c|c|c|c|}
\hline Specialization & No. of Colleges & Specialization & No. of Colleges \\
\hline General & 25430 & Commerce & 295 \\
\hline Agriculture & 298 & Teacher Training & 2912 \\
\hline Architecture & 170 & Medical Ayurveda & 218 \\
\hline Arts & 865 & Nursing & 1163 \\
\hline
\end{tabular}

Source :UGC Annual Report 2018-19

As we can see the table above that there were 295 commerce colleges were in India in 2018-19. In comparison with other streams like Nursing 1163,
Teacher 2912, Agriculture 298 etc. the number of commerce colleges are low.

Table 2

Major Discipline /Subject wise Ph.D/ M.Phil Enrolment* : Universities and colleges: 2018-19

\begin{tabular}{|l|c|c|c|c|c|c|}
\hline \multirow{2}{*}{ Discipline } & \multicolumn{3}{|c|}{ Students Enrollment } \\
\cline { 2 - 7 } & Men & Women & Total & Men & Women & Total \\
\cline { 2 - 7 } & 3586 & 2470 & 6056 & 35 & 31 & 66 \\
\hline Agriculture & 1728 & 1373 & 3101 & 806 & 1110 & 1916 \\
\hline Area Studies & 2445 & 2906 & 5351 & 612 & 2 & 2 \\
\hline Commerce & 18 & 26 & 44 & & 2078 \\
\hline $\begin{array}{l}\text { Forensic } \\
\text { Science }\end{array}$ & 185 & 271 & 456 & 97 & & 238 \\
\hline $\begin{array}{l}\text { Cultural } \\
\text { Studies }\end{array}$ & & & & & & 2 \\
\hline
\end{tabular}

Source :UGC Annual Report 2018-19

If see the Table 2 which clearly shows that significant amount of students were enrolled during the 2018-19 in PhD. and M.Phil Program in Commerce. It is the indication that still students wants to pursue research in commerce and wants to make career in it. Both Male and Female candidates were enrolled but female candidates' number was higher than male.

\section{CHALLENGES TO COMMERCE EDUCATION IN INDIA}

With a quantum bounce in the business world, the need to rethink and reinforce the trade training in India has expanded. Commerce Education is considered as the foundation of sequential advancement of business in the country. Thus, it is significant that a part as critical as this one, there are no imperfections in the framework. Here are a few difficulties that trade instruction is or will look in India.

- Changing International and Indian Economic Sectors.

- $\quad$ Rising issues in business, worldwide economy and the board.
- Internationalization or globalization of Financial Market in the global economy.

- Methodologies and difficulties to control Inflation.

- Role of Foreign Institutional Investment and Foreign Direct Investment.

- $\quad$ Role of IMF and World Bank.

- Govt. strategies for acquisitions and mergers.

- Lack of knowledge about commerce at school level as commerce education is not introduced at school level in many States.

- Poor teaching in many colleges forcing many students to go for tuitions, which means additional cost and effort

- It is more content oriented rather than skill and practice oriented.

- Untrained and ill-equipped teachers.

- Import and fare of business, industry and exchange.

- Challenges in the current market as with respect to the international scenario 
- Techniques and difficulties for the securities exchange

\section{OPPORTUNITIES IN COMMERCE EDUCATION IN INDIA}

There are many avenues of career for the commerce students to prove their talent and to earn well. It can be said that commerce education is the important part of the economy. If the well trained human resource in the field of commerce and finance will produced then surely every economy can be flourish. At the undergraduate level, Bachelor of Commerce, a three year full time course. And Master of Commerce at the postgraduate level can be done. After completing course in the field of Commerce, a student can join any private institute or government organization as a specialist in any of the Commerce stream and they can also pursue professional courses such as Company Secretary, Chartered Accountant, and ICWA. A graduate in Commerce can also opt careers in financial services as a Financial Consultants, Stock Brokers, Merchant Bankers, Budget Consultant, Financial Portfolio Manager, Project Formulation Manager, Tax Consultants. Careers in Management are also available in the field of Personnel Management, Production Management, Financial Management, Marketing Management, and Material Management, other areas of Management such as Hotel Management, Hospital Management, Tourism Management, Event Management, Office Management, Export and Import Management. In the Bank, call for Commerce graduates and post graduates with specialization of Banking. Many Multinational companies hire commerce students every year in bulk and provide good salary and perks.

\section{SUGGESTIONS}

- Skilled and trained teachers should be recruited

- Focus on practical, field training.

- Govt. Should start new faculty development program for commerce teacher.

- Courses and syllabus should be design according to current market need.

- Teacher and students ratio should be improved.

\section{CONCLUSION}

It has been discovered that commerce education in India, presently confronting some difficulty. It has occurred because of the issues excited because of the globalization, changing in Indian financial segments and so on. Commerce student gets jobs in business enterprises, corporate sector etc. So if they are growing, economy is growing then they will have greater chance but in last few years all economic indicators are showing negative indications. Still there are some acceptable open doors for the business understudies in the event that they genuinely put endeavors and get some took on some great courses like CA, ICWA, CS and so forth. All rely on the one's ability and true endeavors. Based on the study it tends to be recommended that government's meddle is essential and in new education policy 2020 , it is normal that business training and commerce education in India will thrive.

\section{REFERENCES}

1. Dr. Partap Singh.2014. The Changing Face of Commerce Education. Udyam: Journal of Social Science, Volume 1, Issue 1(sep-2014) ISSN 23940689. International Group of Multidisciplinary Educational \& Technical Activities, www.igmeta

2. Dr. Partap Singh.2014.Agriculture Credit in India: An Analytical Study, "International Journal of Latest Trends in Engineering and Technology (IJLTET)", Vol. 3 Issue 3 January 2014326 , (ISSN: 2278-621X)

3. Dr. Nilesh B. Gajjar .2013. Relevance of commerce education in present era. Management and pharmacy vol. 2, issue (ijrmp) ISSN: 2320-0901

4. Ajay Kumar Singh.2012.Activity based learning in commerce education: Analysis of preferred learning styles and instruction Approach. Indian Journal of Commerce. Vol 65. No.2. April- June 2012

5. Rajkumar and H.J.Ghosh. Roy.2012.Learning outcomes of summer training. Journal of Commerce. Vol 65. No.2. AprilJune 2012

6. Dey, N.B.1996. Globalization of Business Education in India, The Indian Journal of Commerce, $V$ o $l$. XLIX, Part-IV, No. 189, December, 1999, Edited by R.K.Jena.

7. Chattopadhya P.1987 .Commerce Education, Commerce Education in India, Edited by Devadas Bhorali, New Delhi: Deep\& Deep Publications,

8. Desai Armaity .1993. Commerce Education: Objectives and reorganization, Commerce Education in India, Edited by Devadas Bhorali., Deep\& Deep Publications, New Delhi.Gautam Arindam,www.coolavenues.com/know/Accessed on 15 thAugust, 2010;

9. Parida and Parida .1906. Globalization: Prospective of Business Education in India.The Indian Journal of Commerce. Vol. XLIX, Part-IV, No. 189, December, 1999, Edited by

10. R.K.Jena.Sikidar S.and Das D. 2006. Commerce Education: Professional Impulses. Professional Promoter, edited by Dr. Jatindra Nath Saikia and published by the Principal, Golaghat Commerce College, Golaghat, Assam.

11. The University Education Commission .1949.The Report of University Education Commission-1949, p. 174).

12. Gupta Vipin, Gollakota Kamala and Sreekumar Ancheri .2003.Quality in Business Education: A Study of the Indian Context",Paper Prepared 
forPresented at the Business Education and EmergingMarket Economies: Trends and Prospects Conference, Technology Sqare, Atlanta, Georgia, USA, November 7, 2003. International Journal of Latest Trends in Engineering and Technology (IJLTET) Vol. 6 Issue 1 September 2015319 ISSN: 2278-621X

13. Khairoowala, Z. U. Siddiqui Saif, ed. Sheikh Mustafa S.M. " $C$ o $m$ m e $r$ c e Education in India:Problems and Prospects : India Journal of Business of Business papers, Patna University, Patna, Vol. 2 \& 3, Dec.-June, 2002, No. 4\& 5, pp. 76-814.

14. Swaminathan D.1995.Panel Discussion on Commerce Education: Integrating with Emerging Technology", 58th All India Commerce Conference, organized on 27th Dec. 2005 at Varanasi.

15. Mohiuddin Sagmi.2005.Commerce Education in the new Millennium: Challenge and opportunities, Business Peep, Vol. 1 No. 1, 2005, pp. 1-5.7.

16. Paperman, Jacob, B. and Chandra Gyan .1983.Accounting Internships: An Aid to Recruiting", Applied Business Administration Quarterly, spring, pp 8-

17. Reddy.2007.Revitalising Commerce Education.Vidyasagar University,Journal of Commerce, Vidyasagar University, vol. 12, March 2007, pp. 1-129.

18. Kokklki.2011. Industry and commerce education a strength and weakness analysis Indian Journals.com

19. Eresi, K. .1994. Recent Trends in Commerce and Management Education. Strling Publishers Private Limited.1990

20. Kokklki, G. V. 2011. Industry and commerce education - a strength and weakness analysis. Indian Journals.com National Policy on Education 1986 an Appraisal, Doaba House, New Delhi.1989

21. Reddy, D. O. 2007. Revitalising Commerce Education.Commerce and Management Education in India, Ashish Publishing House, New Delhi. 